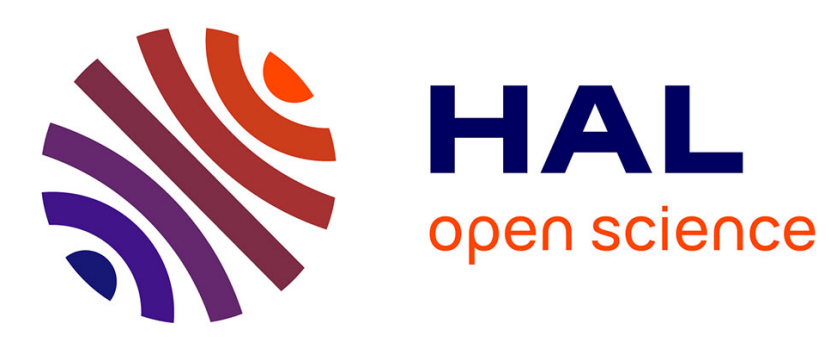

\title{
Cluster life cycles: the case of the shipbuilding industry cluster in South Korea
}

Dong-Ho Shin, Robert Hassink

\section{To cite this version:}

Dong-Ho Shin, Robert Hassink. Cluster life cycles: the case of the shipbuilding industry cluster in South Korea. Regional Studies, 2011, pp.1. 10.1080/00343404.2011.579594 . hal-00712370

\section{HAL Id: hal-00712370 \\ https://hal.science/hal-00712370}

Submitted on 27 Jun 2012

HAL is a multi-disciplinary open access archive for the deposit and dissemination of scientific research documents, whether they are published or not. The documents may come from teaching and research institutions in France or abroad, or from public or private research centers.
L'archive ouverte pluridisciplinaire HAL, est destinée au dépôt et à la diffusion de documents scientifiques de niveau recherche, publiés ou non, émanant des établissements d'enseignement et de recherche français ou étrangers, des laboratoires publics ou privés. 


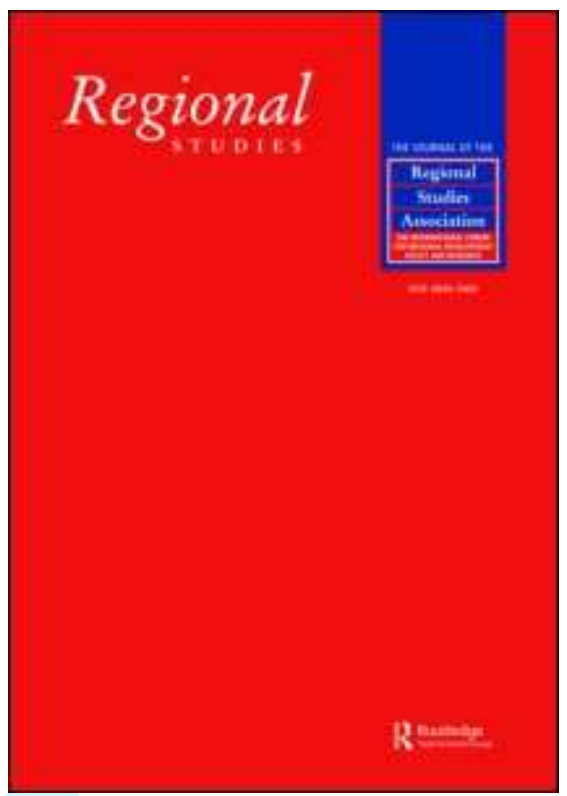

\section{Cluster life cycles: the case of the shipbuilding industry cluster in South Korea}

\begin{tabular}{|r|l|}
\hline Journal: & Regional Studies \\
\hline Manuscript ID: & CRES-2009-0157.R2 \\
\hline Manuscript Type: & Main Section \\
\hline JEL codes: & $\begin{array}{l}\text { O14 - Industrialization; Manufacturing; Service Industries; Tech } \\
\text { Choice < O1 - Economic Development < O - Economic } \\
\text { Development, Technological Change, and Growth }\end{array}$ \\
\hline Keywords: & cluster life cycle, shipbuilding industry, South Korea \\
\hline
\end{tabular}

\section{SCHOLARONE Manuscripts}


Cluster life cycles: the case of the shipbuilding industry cluster in South Korea

Dong-Ho Shin

Dept. of Urban \& Real Estate Studies, Hannam University, Daejeon, South Korea, e-mail: dhshin@hnu.kr

$\&$

\section{Robert Hassink}

Dept. of Geography, University of Kiel, Germany, e-mail: hassink@geographie.uni-kiel.de

Paper forthcoming in the special issue in Regional Studies on "Cluster life cycles - Theory, Empirics and Policy Implications"

(Received June 2009: in revised form February 2011) 


\begin{abstract}
Although South Korean academics and policy-makers have applied industrial districts, regional innovation systems and clusters to study and to promote regional economic development, these concepts have little power to explain the changing economic landscape over time. This paper tackles this question with the help of the concept of cluster life cycle and shipbuilding as a case. It concludes that the cluster life cycle concept is useful for analyzing and explaining spatial industrial dynamics in Korea, but the distinction between industry life cycle and cluster life cycle is not very relevant in the case of shipbuilding.
\end{abstract}

Keywords: cluster life cycle, shipbuilding industry, South Korea

JEL codes: O14 - Industrialization; Manufacturing; Service Industries; Tech Choice < O1 Economic Development < O - Economic Development, Technological Change, and Growth

\title{
1. Introduction
}

Despite pronounced interest in the causes and policy lessons of South Korea's economic miracle, relatively little sound academic work has been done on the geography of its success from a theoretical and dynamic perspective (HASSINK and SHIN, 2008). Although South Korean academics and policy-makers have applied industrial districts (PARK and MARKUSEN, 1999), regional innovation systems (CHUNG, 2002) and clusters (LEE, 2009) to study and to promote regional economic development, these concepts have little power to explain the changing economic landscape over time. This paper focuses on this question, namely the genesis, emergence and development of industrial clusters in South Korea. It analyzes the life cycle of the shipbuilding industry cluster over time and explains the different stages of development. Finally, it focuses on the factors affecting the life cycle of the cluster. 
Earlier articles on the shipbuilding cluster in South Korea focused on the emergence of the cluster (HASSINK and SHIN, 2005) and potential lock-ins hindering its development in the future (EICH-BORN and HASSINK, 2005). These articles did not deal with the full development course of the cluster life cycle, neither did they compare the industry and cluster life cycle, issues we will deal with in this paper. Moreover, in this article we will use the cluster life cycle concept to put the development of the shipbuilding in perspective in a similar vein to VAN KLINK and DE LANGEN'S (2001) work on the shipbuilding cluster in the Northern Netherlands, and also examine the validity of the core themes of path dependence and cluster life cycle, as described by MENZEL and FORNAHL (2010). This paper will therefore not only contribute to understanding the spatial-industrial dynamics of South Korea, it will also put empirical flesh on the emerging conceptual bones around cluster life cycles. Moreover, in a broader perspective it will also contribute to the emerging paradigm of evolutionary economic geography (BOSCHMA and MARTIN, 2010) by analysing the similarities and differences between the industrial and cluster life cycle and by dealing with the role of national and regional industrial and cluster policy in an evolutionary perspective (see HASSINK and KLAERDING, 2011).

The theoretical part of the paper (Section 2) will discuss recent work on clusters, cluster life cycles and cluster dynamics in an evolutionary perspective. Section 3, which comprises the main empirical part of the paper, will describe, analyse and explain the life cycle of the shipbuilding cluster in South Korea. This section will draw on existing work by the authors on the shipbuilding cluster in Gyeongnam (HASSINK and SHIN, 2005), expanded by recent publications, expert interviews with officers of the Korean Shipbuilding Association (KOSHIPA) and some policy planning institutions, such as the Korean Institute of Economics and Trade, local 
governments and telephone interviews with managers and engineers of major Korean shipbuilders, such as Hyundai, Samsung, and Daewoo.

\section{Clusters from an evolutionary perspective}

Before dealing with cluster life cycles and the characteristics of the different stages of development in a theoretical way, we will introduce the cluster concept and its critics in a nutshell.

\section{1) Clusters}

Much of the literature focuses on developing explanations for the rise of regions in order to contribute to regional economic development theories and learn policy lessons to apply to other regions (SCOTT, 1988; STORPER, 1997; STORPER and WALKER, 1989; OECD, 2001, 2007).

Economists have also addressed the question of why internationally successful industries tend to concentrate in a few nations or regions (PORTER, 2000).

Thus, geographical ‘clustering' of firms in related industries and its implications for regional development have been debated for a long time now (ASHEIM et al., 2006; CUMBERS and MACKInNON, 2004). There have been intensive discussions about the extent of clustering at a regional level and the potential economic benefits that might be generated by clustering. It is well-known that the spatial co-localisation or 'clustering' of firms and other organisations in related industrial sectors has the potential for economic and innovation benefits. These benefits have been labelled variously as 'external economies of agglomeration', which support the cooperative and competitive relationships between firms and enable the effectual development and manufacture of products. STORPER (1997) argues that traded interdependencies may be based on upstream and downstream linkages between buyer and supplier firms and untraded 
interdependencies include resource bases, skills, technologies and governance agencies. Proximity is said to provide social solidarity and trust, face-to-face contact and a pool of skills and know-how.

According to PORTER (2000, p. 16) "a cluster is a geographically proximate group of interconnected companies and associated institutions in a particular field, linked by commonalities and complementarities." Important characteristics are economic interaction in a value chain, strategic inter-firm relations, specialisation, co-operative competition, innovation and diffusion and shared cultural context and interpretation schemes (VAN KLINK and DE LANGEN, 2001). On the basis of theoretical thoughts on geographic clusters by PORTER (2000) and ENRIGHT (2003), a rapidly increasing number of policy initiatives to support clustering of industries has emerged in many countries of the world (see for instance, PORTER, 2000; ASHEIM et al., 2006; OECD, 2001, 2007).

\section{2) Critical voices}

Although many authors assume that geographic clusters create economic and innovation advantages, some arguments run counter to the 'benefits from localisation' thesis (ENRIGHT, 2003). Potential disadvantages lie in labour cost inflation, inflation of land and housing costs, widening of income disparities, local congestion, environmental pressure, over-specialisation and, last but not least, lock-ins (MARTIN and SUNLEY, 2003; HASSINK, 2010).

MARTIN and SUNLEY (2003) are very critical of the ambiguities and identification problems surrounding the cluster concept. In fact, the concept bears many characteristics of what MARKUSEN (1999) has coined a fuzzy concept, which is characterised by a lack of conceptual clarity, poor rigour in the presentation of evidence, unclear methodology and difficulties in 
operationalization. One way to solve this problem is to look at different dimensions of clusters. ENRIGHT (2003), for instance, distinguishes between the geographical scope of clusters, the density (dense vs. sparse clusters), breadth of clusters (broad vs. narrow), the depth of clusters (shallow vs. deep clusters), the geographical span of sales (from local to global), the strength of competitive position, the innovative capacity and the ownership structure. Related to these typologies, clusters also vary in terms of their level of activity and self-realisation (ENRIGHT, 2003).

Another criticism concerns the fact that the cluster literature strongly focuses on how clusters function, but not so much on how they develop over time. One useful solution to these problems is to look at different dimensions of clusters and to use a typology of clusters based on development stages. By doing this we put the cluster in an evolutionary perspective.

\section{3) Cluster Life Cycles}

Although we share the concerns of MARTIN and SUNLEY (2003) and other critical voices, we agree with CHAPMAN et al. (2004, p. 394) who stated that: "Instead of simply 'dropping' clusters as rapidly and uncritically as the term was adopted (MARTIN and SUNLEY, 2003), we need to assess and 'unpack' the underlying concept, stepping back from the clusters label and the specifically Porterian assumptions and claims that underpin it. In moving beyond such 'deconstruction' to 'reconstruction', what seems to be required is not a single, overarching theory but the conceptual abstraction of key notions and relations which can then be subjected to detailed empirical scrutiny." We see the cluster life cycle idea and its relation to evolutionary economic geography (MARTIN and SUNLEY, 2006; BOSCHMA and MARTIN, 2010; HASSINK and KLAERDING, 2009) as such an approach towards reconstruction with a strong emphasis on empirical testing. Related to older concepts, such as new industrial spaces (SCOTT, 1988; 
STORPER and WALKER, 1989), windows of locational opportunity (BOSCHMA and VAN DER

KNAAP, 1999) and path dependence and path creation (MARTIN and SUNLEY, 2006), recent conceptual work on cluster life cycles has been done by MENZEL and FORNAHL (2010), PRESS (2006), and LORENZEN (2005). The latter asked three crucial questions, namely: why do clusters arise? why do clusters decline? and why do clusters shift to new economically viable development paths? Our paper can be considered as an empirical contribution to this recently developing theoretical literature.

Looking in detail at the different stages of a cluster life cycle, VAN KLINK and DE LANGEN (2001) exemplary distinguish between the development, expansion, maturation and transition stages of a cluster life cycle. Others, such as MENZEL and FORNAHL (2010), distinguish between emergence, growth, sustainment and decline (for similar classifications, see GILSING and HOSPERS, 2000; LORENZEN, 2005; ENRIGHT, 2003).

In addition to distinguishing between different stages, authors also attach specific characteristics to the different stages of a cluster life cycle. VAN KLINK and DE LANGEN (2001) distinguish the following six differing characteristics through the life cycle of a cluster: character of the value chain, strategic relations, cluster dynamics (entrants, exits), co-operative domain, determinant for success and the role of the government (Table 1).

MENZEL and FORNAHL (2010) pay much attention to the changing character of knowledge through the life cycle of a cluster. According to them, the heterogeneity of knowledge in clusters changes through the life cycle of a cluster, as becomes clear in Fig. 1. It is very high in early stages of the life cycle and then decreases strongly through the life cycle. The way the heterogeneity of knowledge in particular is exploited forms the main difference between 
clustered and non-clustered firms (MENZEL and FORNAHL, 2010). The paradox of a cluster is that specialisation leads to homogeneity of knowledge, which facilitates synergies, whereas a large heterogeneity of knowledge facilitates continuous adjustment to changing external circumstances. Clustered firms show higher growth rates and are more innovative than nonclustered firms during the growth and sustainable stages of the life cycle (Fig. 2) (MENZEL and FORNAHL, 2010). Geographic concentration increases in early stages but decreases in mature stages.

(FIGURE 1 ABOUT HERE)

(FIGURE 2 ABOUT HERE)

\section{(TABLE 1 ABOUT HERE)}

There seems to be most disagreement about the explanation of the emergence of a cluster and about what happens after decline sets in. KRUGMAN (1991) claims that the emergence of a cluster is often a historical accident, whereas KLEPPER (2007) stresses that clusters emerge where companies with superior routines in older, related industries are located. Successful spin-offs, the main basis for the emergence of clusters, stem from these superior companies. A renewal or adjustment in the decline stage can take place through a "step back", which is only possible due to the generation of a new heterogeneity of knowledge, which also means a shift in the thematic boundary of the cluster. Increased heterogeneity of knowledge can then lead to a new growth stage (see Fig. 1) (MENZEL and FORNAHL, 2010). 
Most authors stress the non-deterministic character of the cluster life cycle. Although elements of path dependence can explain changes ex post, strong contingent factors also influence the development of a cluster (VAN KLINK and DE LANGEN, 2001, p. 452). The actual dynamics of a cluster depend both on external contingent events as well as internal dynamics. According to MENZEL and FORNAHL (2010), the development of a cluster is not from the left to the right, but a steady oscillation between left and right due to the changing heterogeneity of knowledge in the course of a cluster (Fig. 1). The crucial question is whether the heterogeneity of knowledge is put to use, and that, in turn, depends on the absorptive capacities of companies and organisations in a cluster. Moreover, a cluster does not evenly develop as a whole, but parts of a cluster can be in different stages.

The non-determinist character of clusters can be further elaborated on by comparing industry with cluster life cycles. Clusters follow different growth paths within the same industry (MENZEL and FORNAHL, 2010) (see for instance Silicon Valley vs. Boston elaborated in the study carried out SAXENIAN, 1994). Clusters are therefore prone to peculiar local conditions.

To summarise, many authors have recently elaborated on the life cycle of clusters (STORPER and WALKER, 1989; MENZEL and ForNAHL, 2010; GILSING and HoSPERS, 2000; POPP and WILSON, 2007; VAN KLINK and DE LANGEN, 2001). They mainly agree on the characteristics of a growing cluster. There is, however, disagreement about how to explain the emergence of clusters and about the development of declining clusters. From these theoretical elaborations, we derived the following research questions, which we will be tackled in the following empirical part of this paper on the life cycle of the shipbuilding cluster in South Korea: 
Research question 1: Are clustered firms more competitive in the middle stages of a cluster life cycle? Do non-clustered firms actually perform better than clustered firms in the declining stage?

Research question 2: Does the role of the firm in the value chain change from differentiation, to specialization, to reorientation through the course of a cluster life cycle?

Research questions 3: Do the number and composition of firms change from many entrants and no exits to a few entrants and a few exits to hardly any entrants and many exits, through the course of a life cycle?

Research question 4: Does the role of the government change from providing information on local know-how and market expansion in early stages of the life cycle to stimulating neue Kombinationen in later stages?

Research question 5: Is the heterogeneity of knowledge very high at the early stage of a cluster life cycle and does it decrease strongly in later stages?

Research question 6: Does the geographic concentration of firms in a cluster increase in early stages but does it decrease in mature stages of the cluster's life cycle?

\section{Korea's Economy and Shipbuilding Industry}

Before analyzing the Korean shipbuilding cluster (Section 5) and its life cycle (Section 6), we will describe the context of Korea's economy and shipbuilding industry in this section and its development in the next section. 
In terms of land mass, South Korea is a small country with only $99,000 \mathrm{~km}^{2}$ of land, but it can be considered a medium-scale country as it is home to 50 million people. While it was colonized by Japan between 1910 and 1945, its economic and social conditions were very poor and politically unstable by the early 1960s. The country, however, has been drastically transformed into a modern society since then. Supported by strategic economic development policies, Korea's GNP per capita, for example, grew from 81 dollars in 1960 to 1,510 dollars in 1980, and to 18,374 dollars in 2006. While the growth was led mainly by manufacturing activities, the share of manufacturing activities among GNP, measured by sales amount, grew from $16.2 \%$ in 1970 to $24.7 \%$ in 2006 , while that measured by employment also grew from $9 \%$ in 1970 to $28 \%$ in 1980 , sustaining similar levels by the 1990s. These changes created significant impacts on the industrial and social landscape of Korea, including the shipbuilding industry.

Korea emerged as a top ranking country in the merchant shipbuilding industry in the recent past (STOPFORD, 2008, 2009; KIM, 2006; CHO and PORTER, 1986; WoO, 2003; GLEN, 2006) (Fig. 3). While the country's traditional shipbuilding industry was scattered along the coastal areas of the whole country, a new path of modern shipbuilding activities was formulated around port cities of the southeastern region: Ulsan, Busan, Changwon, and Geoje, beginning from the early 1970s (Fig. 4). While the cluster was initiated by three major conglomerates, Hyundai was the first initiator and constructed a large shipyard in Ulsan, an industrial city located in the southeastern coastal area. Hyundai eventually became a dominant figure in building large vessels such as crude oil carriers, LNG (Liquefied Natural Gas) carriers, and drilling ships. Although it started with imported modern shipbuilding technologies from overseas (AMSDEN, 1989), it now has not only internalized most of these technologies but also established systems of technological advancement domestically. Although it started with strong governmental assistance, the Korean shipbuilding industry has acquired sustaining technological and financial capacity within the 
private sector, forming a large industrial cluster in the southeastern region. Below the authors will introduce the details of the growing cluster.

(FIGURE 3 ABOUT HERE)

(FIGURE 4 ABOUT HERE)

\section{The Stages of Developing Shipbuilding Industry in Korea}

1) The Period Prior to the $1970 \mathrm{~s}$

Although Korea was active in building ships from the ancient period, its modern shipbuilding is a recent phenomenon. While a major step toward becoming a giant shipbuilder was made in the early 1970s, the roots of the Korean shipbuilding industry can be traced back to the 1880 s. As Japan is located as close as $240 \mathrm{Km}$ away, the first Japanese shipbuilder, called Tanaka Steelship Corporation, established a shipyard in a coastal city, Busan, in the middle of the 1880s (KOSHIPA, 2009). From this time on, the Korean shipbuilding industry benefited from the arrival and continuous growth of Japanese shipbuilders during the colonial period (1910-1945). While the Japanese legacy was sustaining to the Korean shipbuilding industry even after its independence, no significant changes took place in the 1940s and the 1950s. Although there were small-scale shipbuilding activities scattered around port cities of the southeastern region, most of these were focused mainly on small and medium-sized ships and boats, and there were very few changes in the structure of the industry. Beginning from the early 1960s, the Korean government initiated a series of ambitious five-year economic plans to promote industrial growth in Korea, including shipbuilding. 
A drastic change was made in the 1970s, when the Korean government's industrial policies greatly emphasized machinery and heavy industries, including the automobile and shipbuilding industries (AMSDEN, 1989). From this time, a new path was set in motion in the Korean shipbuilding industry. The path was created by three major Chaebol companies: Hyundai, Daewoo, and Samsung. The Chaebol group shipbuilding companies began to build large vessels, i.e., oil carriers and LNG ships, in the early stage; however, they greatly diversified their products based on advanced technology at later stages.

\section{2) During the 1970s and $1980 \mathrm{~s}$}

This new path in the Korean shipbuilding industry was led by the aggressive corporate leaders of Hyundai, Samsung, and Daewoo, and supported by strong governmental policies. While the Korean central government, as a part of its five-year economic plan policies, was geared to promote heavy industries, such as steel-making, machinery and shipbuilding during the 1970s when the international market for shipbuilding was rapidly expanding, some conglomerate leaders attempted to make use of the opportunities provided by the market and the government (HASSINK and SHIN, 2005; WOO, 2005; LEE and RYU, 2008).

For example, the earliest entrant, Hyundai, originally had a plan to build three medium-scale shipbuilding docks (for the scale of 100,000 GT (Gross Tonnage), 60,000 GT and 35,000 GT, respectively), in September 1970, but the company drastically changed its plan to construct super-large shipbuilding docks instead (KOSHIPA, 2009). This was because the Korean government was strongly encouraging shipbuilders to go for large vessels to take advantage of the rapidly expanding international market. Eventually, Hyundai, whose owner was known for his aggressive business style, built shipbuilding docks with a capacity for ships as big as 500,000 
GT. The company was successful in building as many as five Very Large Crude Oil Carriers (VLCCs), all for export overseas. In addition, the company expanded dock capacity further to accommodate building a huge ship as big as 700,000 GT. In June 1974, Hyundai completed a large dock of $383 \mathrm{M}$ in length, $80 \mathrm{M}$ in width and $12.7 \mathrm{M}$ in height. This shipyard was also equipped with $1,050 \mathrm{M}$ of painting walls, two Goliath cranes that could handle loads as heavy as 450 Tons, and other modern shipbuilding machines and equipment, such as large N/C (Numerical Control) cutters. In addition, Hyundai established a new company in 1975 that specialized in repairing large ships, called Hyundai Mipo Shipbuilding Company.

Samsung took part in the race by buying-out one of the existing shipbuilders, called Woojin, located in Geoje, Gyeongnam Province, and completing a major shipyard in 1977 (HASSINK and SHIN, 2005; LEE and RYU, 2008). Another existing company, Korean Shipbuilding Corporation also constructed a major shipyard in Geoje in 1978 but it was merged into Daewoo.

Geoje, a traditional fishing town in the south was growing into an industrial city with Samsung and Daewoo. Among these shipbuilders, Hyundai was the leading power as it was able to make a deal with MetroStar, a Greek company, even during the period of building its shipyard. In this way, Korea's shipbuilding industry grew to have a capacity of building 2,800,000 GT of ships by the end of 1970s, which was 2.8 times of the capacity in 1974 (KOSHIPA, 2009).

While the conglomerates in the private sector were busy with constructing large shipyards, the Korean government of the 1970s was also assisting the industry with political, financial and educational activities. It established a governmental research institute specifically for shipbuilding and ocean studies in 1973, promulgated a law to promote shipping and shipbuilding industry in 1976 and organized a semi-government business organization, called the Association 
of Korean Shipbuilders, to provide the industry with various information related to domestic and international shipbuilding (see Table 2).

The Korean shipbuilding industry grew by 30\% every year between 1976 and 1985 (KOSHIPA, 2009). The employment effect was also significant as the number of employees in the industry tripled in the same period. During the late 1970s and the 1980s, however, the industry suffered from the Oil Shocks. Aggressive investment in the previous decade resulted in a significant burden on the industry. During the early 1980s, many international shipbuilders suffered greatly from downsizing international markets for large vessels. The problem was exacerbated by over investment in the previous years, making some production facilities and equipment redundant. Korean shipbuilders suffered from the same problem. However, the three major Korean shipbuilding companies benefited from the growing international shipbuilding market in the mid1980s and were able to grow rapidly. Samsung, for example, expanded two major docks in 1979 and 1983, respectively. Despite the over investment of the 1970s, which led to a major restructuring process in the following decade, such aggressive investment is believed to have helped Korea to grow as a giant shipbuilder in the present era. The low value of the Korean currency and low labor costs that made the Korean shipbuilders more competitive, compared to Japan in particular, were temporary conditions that existed only in the middle of the decade. Nevertheless, this circumstance greatly helped the Korean shipbuilders to move to the top of the international shipbuilding industry (Interview with Chong-Hyub Han, KOSHIPA, Dec 12, 2009.)

The decade beginning in the mid-1980s was quite favorable for Korean shipbuilding. The main competitors in Japan were suffering from the expensive Japanese Yen. While the industry was dominated by a few large players, most of the companies were greatly expanding and stabilizing 
their areas of specialization, scale of production, diversity of product mix, and managerial and technological knowledge.

\section{(TABLE 2 ABOUT HERE)}

\section{3) The Period since 1997}

The growing shipbuilding industry in Korea encountered a major obstacle in the late 1990s. The whole Korean economy was seriously affected by the Asian economic crisis in 1997, and the shipbuilding cluster was not an exception. While the Crisis forced shipbuilding conglomerates go through a process of critical changes, one of the three shipbuilders, Daewoo, which was one of the Daewoo Chaebol group companies, separated from the group and became independent. The Daewoo group as a whole, in fact, was broken into parts as the Chaebol was financially unsound with high debt ratio, as much as 526\% (MINISTRY OF FINANCE AND ECONOMY, 1999, p. 144). Daewoo shipbuilding was allowed to be independent and survive the restructuring process. It was successful in overcoming the Crisis as the company was able to creep out from under the debt problem, recover a sound financial structure and demonstrate its ability to manage a large number of production orders from overseas shipping companies. In this way, the Crisis made Daewoo even more competitive (see Daewoo's performance in Table 2).

The restructuring process in the late 1990s contributed to making the Korean shipbuilding cluster more coherent by forcing less competitive companies out of business and by creating new and more competitive shipbuilders, mainly at the medium scale, often led by innovative entrepreneurs. STX, for example, was created by merging several less competitive, mediumscale shipbuilders, such as Daehan. While Daehan, a medium scale engine-maker, was unable 
to survive, an employee overtook its managerial authority and ownership to create a comprehensive shipbuilder. The STX group as a whole has now grown to employ 51,500 people and operate many subsidiary companies, including shipbuilding, engines, heavy industries, energy and construction at various locations. In 2006, it made a major step toward being able to make cruise ships by acquiring a Norwegian cruise ship maker called Aker Yards (Interview with Jin-Keun Kim, Gyeongnam Development Institute, May 17, 2010).

\section{The Korean Shipbuilding Cluster}

The Korean shipbuilding industry is heavily concentrated in the southeastern region of Korea and plays a very important role in the Korean economy. The industry developed from a couple of cathedrals in the desert into an innovative cluster with some Porterian characteristics (HASSINK and SHIN, 2005). The industry as a whole provides nearly 120 thousand jobs, contributes $5 \%$ of the country's GDP, and constitutes 7.5\% of overseas sales (KOSHIPA, 2008), where the shipbuilding industrial cluster plays a key role. The major cluster established in the southeastern region is composed of four major city-regions, centered on Busan, Ulsan, Changwon, and Geoje (Tables 3, 4, Fig. 4).

\section{(TABLE 3 ABOUT HERE)}

Hyundai, Daewoo, and Samsung, all of which are located in the southeastern cluster area, have established strong linkages with their own sub-contractors, but loosely dedicated subcontractors also provide products and services independently to more than one large company. While there are independent parts and materials and service providers (see KIM et al., 2005; KIM, 2008), these small companies are spread across three provincial level administrative 
areas in the south, including the Province of Gyeongnam and the metropolitan cities of Ulsan and Busan. This region, which includes Korea's second largest city, Busan, has been a center of petrochemical, machinery, and heavy industries, including refining crude oil, shipbuilding, automobile, and machinery. The whole region, stretching from Busan to Geoje, is home to about 8 million people and continues to play a key role in the modernization of the Korean economy since the colonial period under Japan.

The Korean shipbuilding cluster, however, is not exactly a complete cluster. Rather, it operates strong extra-cluster linkages. In fact, a lot of labor and materials are mobilized from outside: steel plates, a major material input to the cluster, is supplied mainly from a steel giant, POSCO (see AUTY, 1990; D’COSTA, 1994), located in the city of Pohang, while a considerable portion of engineering personnel and scientists are recruited from other regions, such as Seoul and Daejeon, where many of high-ranking universities are located. Table 3 indicates that $76.7 \%$ of the Korean shipbuilding firms and $88.4 \%$ of the workers are located in two major provincial level areas: Ulsan and Gyeongnam (Data for 2007, from KOREAN NATIONAL StATISTICAL OfFICE, 2008). Shipbuilding activities clustered in the southeastern region are mainly characterized by production activities, while the Seoul and Daejeon regions, outside the cluster, provide higher quality resources, such as engineers, scientists and R\&D services (Interview with Gyu-Bae Kim, Hyundai Heavy Industries, May 17, 2010 and JongSoo Seo, Samsung Heavy Industries, May 6, 2010.)

(TABLE 4 ABOUT HERE)

\section{Cluster Life Cycle}

As is pointed out in the theoretical part of this paper, MENZEL and FORNAHL (2010) and VAN KLINK and DE LANGEN (2001) have identified four stages of cluster life-cycle: development, 
expansion, maturation and transition. While LORENZEN (2005) raises questions about the reasons for the emergence of and changes in industrial clusters, GARUD and KARNOE (2001) argue that a new path is not created by "historical accident"; rather, it is created by entrepreneurs' mindful deviation (see also MARTIN and SUNLEY, 2006). Based on the previous historical accounts of the Korean shipbuilding cluster, the following sub-sections will further illustrate the nature of the cluster by commenting on the themes of the cluster life cycle, such as genesis, development and change.

\section{1) The Genesis}

In addition to traditional shipbuilding technology, which was focused mainly on small and wooden boats without mechanical power, the Japanese introduced new shipbuilding technology to Korea during the colonial period, i.e., 1910-1945. The new technology made steel ships and medium scale ships with power engines. Even if such technology did not directly contribute to the modern shipbuilding industry in Korea, it helped the growth of the industry. The existing shipbuilding activities prior to the 1970s were a large foundation on which the current shipbuilding cluster could be grown, as they supplied parts and materials to the modern sector. Therefore, it can be said that the Korean shipbuilding cluster was not created from a vacuum; rather, it grew from the base of traditional shipbuilding, modernized by the Japanese influence especially after 1910.

Considering the Korean shipbuilding case, it is accurate to say that the new path was set by entrepreneurs' 'mindful deviation' under a specific context, consisting of unique governmental policies and market situations in that specific time and nation. While the Korean government pursued aggressive policies of industrialization during the 1970s and 
1980s, an aggressive entrepreneur of Hyundai, Ju-Yung Chung, the founding father of the conglomerate took advantage of the policies and international market environment at that time by heavily investing in the shipbuilding industry. The new path was set not solely by entrepreneurs' mindful deviation, but also with the right context, which was the combination of market circumstance and governmental policies.

\section{2) The Stages of Development and Change}

VAN KLINK and DE LANGEN (2001) identified six criteria to examine the stages of cluster lifecycle: character of the value chain, strategic relation, cluster dynamics, cooperative domain, determinant for success and the role of government. In general, the Korean shipbuilding cluster seems to be moving from the 'developmental stage' to the 'expansion stage,' even if the details of its characteristics do not exactly match with the ones identified by VAN KLINK and DE LANGEN (2001). In terms of value chain, the Korean shipbuilding cluster is composed of three major categories of firms: large, medium, and small. The cluster hosts three very large firms: Samsung, Daewoo and Hyundai, while four medium-sized firms, such as STX and Daesan make the second tier of the hierarchical structure (see Table 2). Prior to the 1990s, Korean shipbuilders focused mainly on large vessels such as oil carriers, which require intensive labor but no advanced technology. Thereafter, they advanced up the value chain to the higher scale of producing LNG carriers, battle ships, submarines, drilling ships and Floating Production Storage and Offloading (FPSO, Interview with Gyu-Bae Kim, Hyundai Heavy Industries, May 17, 2010, Jong-Soo Seo, Samsung Heavy Industries, May 6, 2010 and Chong-Hyub Han, KOSHIPA, Dec 12, 2009.)

Samsung, for example, now focuses on building special ships, such as drilling ships, LNG carriers, and cruise ships, although it started its business with oil carriers (see SAMSUNG HEAVY 
INDUSTRIES, 2009a). A drilling ship that Samsung focuses on is used in drilling holes under the sea to explore natural resources. It requires a structure that can sustain high speed winds and heavy waves, which can be as high as $16 \mathrm{M}$. Though Korean shipbuilders received overseas orders of 43 drilling ships prior to 2008, Samsung acquired 35 of them (see SAMSUNG SHIPBUILDING INDUSTRIES, 2009b). One drilling ship made by Samsung in 2008 is as tall as 100 $\mathrm{M}$ on the surface and can create a hole as deep as $10 \mathrm{Km}$ under the sea floor. One drilling ship costs 400 million dollars, which is four times of the price of a common crude oil carrier. In terms of the value chain, therefore, the Korean shipbuilding cluster is clearly in the 'maturation' stage (Interview with Jong-Soo Seo, Samsung Heavy Industries, May 6, 2010).

In terms of strategic relations, it seems that the Korean shipbuilding cluster is at the 'expansion' stage but strategic relations have not yet fully matured. However, there are strong inter-firm relationships horizontally and vertically. Most of the large corporations in Korea, including shipbuilders, maintain subcontractors (see WoO, 2005; KIM, 2008). The linkages between such subcontractors and their mother companies are very strong; however, these vertical relationships are exclusive to other conglomerates (Interview with Jin-Keun Kim, Gyeongnam Development Institute, May 17, 2010.) While there are very few linkages across Chaebol groups, the linkages within Chaebol groups and with their own sub-contractors are very strong.

Samsung shipbuilding, for example, utilizes electronic parts and related services from Samsung Electronics, which is located in the Seoul region (see HASSINK and SHIN, 2005; KIM, 2008). When Hyundai shipbuilding was constructing its shipyards, Hyundai Construction Company was employed every time. Hyundai shipbuilding also uses paints supplied by Korea Chemical Company, which is another subsidiary of the Hyundai group (Interview with Gyu-Bae Kim, Hyundai Heavy Industries, May 17, 2010.) These relationships have been well established but 
there is no sign of pressure to reconfigure. Other relationships that need to be mentioned are the linkages among large corporations. Large shipbuilding companies share common interests among themselves, even if they compete with each other (Interview with Chong-Hyub Han, KOSHIPA, Dec 12, 2009.) They cooperate with each other for certain purposes in opportunistic ways, as in the fight against EU's legal accusation at WTO (GLEN, 2006). These strategic relations are often maintained through business associations and professional meetings (Interview with Chong-Hyub Han, KOSHIPA, Dec 12, 2009).

VAN KLINK and DE LANGEN (2001) also talk about cluster dynamics. In terms of cluster dynamics, the Korean shipbuilding cluster is also at the stage of 'maturation'. The number of large and medium-size shipbuilders rapidly grew during the 1970s and has steadily grown further during the recent decades. The Korean shipbuilding cluster is diversified in terms of geography, industry, and technology. While the modern shipbuilding industry started in Busan during colonial period and in Ulsan in the early 1970s, the industry expanded to the city-regions of Changwon and Geoje during the 1970s and the 1980s and further extended to the southwest, centered in the city of Mokpo in Jeonnam Province, beginning in the early 2000s. However, this new cluster is mainly focused on production activities, while higher levels of services, technological development and educational activities are supplemented from other areas, such as the southeast and Seoul area (Interview with Jin-Keun Kim, Gyeongnam Development Institute, May 17, 2010 and Hyung-Min Kim, Research Institute of Medium and Small Shipbuilding, May 17, 2010.)

In fact, the new cluster in the southwest can be said to be simply an extension of the existing one in the southeast. The new cluster's survival as a complete and independent cluster is in question 
as the international demand for ship production has drastically shrunk since the 2007 American Subprime Mortgage Crisis.

The scope of activities of the shipbuilding cluster has also greatly expanded. Prior to the 1970s, Korean shipbuilding activities were concentrated on making wooden ships and fishing boats; since then, product mix has been greatly expanded to produce many kinds of ships such as VLCCs, military ships, FPSOs and drilling ships (Interview with Jong-Soo Seo, Samsung Industries, May 6, 2010 and Gyu-Bae Kim, Hyundai Heavy Industries, May 17, 2010). In regards to technology, the Korean shipbuilding cluster started with imported technology mainly from Japan and European countries prior to the 2000s and has been successful in internalizing this imported technology to advance its shipbuilding practice to compete at the international level. This change was systematic. In the early stage, they purchased shipbuilding technology from overseas through various means (see HASSINK and SHIN, 2005, p. 149-151). But they quickly internalized, advanced and eventually used the technology to expand production networks to the southwest and overseas (Interview with Jong-Soo Seo, Samsung Industries, May 6, 2010.).

Since the Asian crisis in 1997, major Korean shipbuilders have aggressively attempted to produce higher value-added ships, requiring advanced technology, and cruise ships, moving away from low cost, labor-intensive ships such as oil carriers and bulk carriers. To build and expand $R \& D$ activities within their own companies, large shipbuilders of the cluster aggressively invested money to acquire higher levels of shipbuilding technology, learned from foreign nationals, and purchased licenses from overseas. This was necessary as, after the crisis, cheap labor became increasingly difficult to find. 
While Hyundai Mipo was established and continued expansion from its own research center in Ulsan, Samsung established a major shipbuilding research center in the city of Daejeon, in the middle of the country. Some governmental research institutions at the national scale have also been promoting technological advancement in the shipbuilding cluster. Korean Institute of Machinery and Materials, for example, which operates two major campuses, one in Daejeon another in the city of Changwon, has been playing important roles in that regard. Korea Electronics and Telecommunications Research Institute (ETRI), a major governmentsupported research center maintaining international levels of technology specializing in semiconductors, telecommunications and information technology, is another example that is active in advancing shipbuilding technology, especially in relation to electronic devices.

In addition to these technology research organizations, some policy planning institutes, supported monetarily by the government also promote the accumulation of knowledge and technology. While KIET (Korean Institute of Economics and Trade) provides economic data and policy alternatives to the national government, some policy research and planning units exist at the local level. Korean Research Center of Shipbuilding Materials and Parts and Research Institute of Small-and-Medium Scale Ships are good examples that provide data, information and policy alternatives to local governments and the business community. These policy planning institutions facilitate information exchange and face-to-face contacts, thereby increasing cooperative relationships among local cluster members, such as firms, governments, technicians, engineers, and related professionals (Interview with Jin-Keun Kim, Gyeongnam Development Institute, May 17, 2010 and Hyung-Min Kim, Research Institute of Medium and Small Shipbuilding, May 17, 2010). 
Samsung has also developed an innovative assembling technique, called 'MegaBlock', which allows the building of large ships in blocks on land (Interview with Jong-Soo Seo, Samsung Heavy Industries, May 6, 2010). The large blocks of a very large ship ranging to more than 300 M long, are made on land; the blocks, each of which commonly weighs up to 3,000 tons, are transported to the water; they are assembled on the water to make a ship; and the ship eventually is launched into the water. While a ship was initially divided into 30 pieces to make the blocks lighter, Samsung has developed a technique that allows them to make 10 pieces of blocks for a large ship, which commonly weigh as much as 165,000 TEU (Twenty-foot Equivalent Tonnage). This is possible by introducing a huge crane that can move a single ship block as heavy as 1,200 tons. In January 2006, Samsung was able to build an oil-carrier for MetroStar that was $274 \mathrm{M}$ long, $50 \mathrm{M}$ wide, and weighed 26,000 Tons. In this way, Samsung is able to build many large ships at the same time since a traditional dock system is not required. 
In terms of the government's role, VAN KLINK and DE LANGEN (2001) mentioned providing information, stimulating market expansion, professionalizing suppliers, and stimulating neue Kombinationen. In the early stages, the national government in Korea designated the shipbuilding industry as a strategic industry. It provided guidelines to stimulate the industry and assisted in the formation of shipbuilding clusters by creating new industrial parks in Ulsan and Geoje. While local governments played very minor roles in the early stages, the roles of local governments in the southeastern and southwestern regions have become much stronger in recent years. The provincial government of Gyeongnam, located in the city of Changwon, for example, has successfully created a multi-million dollar package of central government financial assistance, under the name of 'Changwon Mechanical Engineering Cluster', core elements of which are identical to the shipbuilding industry. Under this program, networks of shipbuilding parts and components suppliers were going to be extended to surrounding areas of core industrial cities, making the cluster more dispersed (WoO, 2005; KIM, 2008). In addition, municipal governments of the southeastern and southwestern regions have also been very active in creating industrial parks to expand and solidify the cluster (Interview with Jin-Keun Kim, Gyeongnam Development Institute, May 17, 2010).

\section{3) Linkages as a Factor of Change}

As stated in the theoretical Section 2, the geographic concentration of firms in a cluster increases in the early stages but decreases in the mature stages of the cluster's life cycle. The increasing role of extra-regional and international linkages is also mentioned in literature on local buzz and global pipelines (BATHELT et al., 2004).

Local dynamic relationships are also found among small-and-medium companies supplying inputs to the shipbuilding companies of the cluster. While some of these are solely dedicated 
to a specific shipbuilding conglomerate, others are less dedicated to a specific company. Among the former, a few large shipbuilders, with local government's assistance, have developed industrial parks close to the shipbuilders to provide cheap land with easy access. The industrial park of Shinhyun-Eup is an example developed by large shipbuilders such as Daewoo (see Woo, 2005). Some local governments have also developed industrial parks to promote the shipbuilding industry by providing less-dedicated parts suppliers with cheap land. Gyeongnam Province in particular is very active in such activities, as seen in the industrial sites developed in Changwon (see KIM, 2008).

While a steel city, Pohang, provides steel plates to the shipbuilding cluster, Changwon, specialized in machinery, supplies engines and other mechanical engineering technology. Engineers needed for this cluster are provided mainly by four major universities: Seoul National University, Busan National University, Korean Marine University and Bukyung National University. While many of these are located in Busan, Seoul National University is located a five hours drive away from the cluster area. R\&D activities contributing to the cluster are also well scattered, forming extra-cluster linkages. While R\&D related to design and production are concentrated on the production sites, such as Geoje and Ulsan, some of the R\&D occurs from the governmental research laboratories of the Daedeok Science Park, located in the city of Daejeon, $300 \mathrm{Km}$ away to the north (see SHIN, 2001). Other R\&D activities are located in the Seoul region, another $150 \mathrm{Km}$ away further to the north (HASSINK and SHIN, 2005; KIM, 2008). Geoje hosts two major shipbuilders: Daewoo and Samsung, each of which has employed more than 10,000 workers on the sites. The industrial city also contains some industrial parks that host subcontractors of the big players (see KIM, 2008; WoO, 2005). These industrial parks, in fact, provide the physical conditions to stimulate easy flow of materials and services between large shipbuilders and their sub-contractors. 
The extra-local linkages of the shipbuilding cluster are not limited to Korea, but extend to other countries. The international linkages are presented in the flow of final products, materials, parts, technology and labor. Korean shipbuilding activities strongly depend upon international markets, as domestic demand is highly limited. Korean shipbuilders also maintain international linkages to acquire parts and materials for two reasons: high quality and low costs. While Korean shipbuilders have been continuously attempting to cultivate higher value added products, some high quality parts and materials were unavailable locally. Therefore, many of the new parts and materials needed for newer models have been imported from overseas. On the other hand, the Korean shipbuilders have been utilizing cheap foreign materials and parts to reduce production costs. Since labor costs in Korea have been increasing since the 1960s and large vessels are now made in block production systems, some parts of large ships could be mobilized from countries with lower labor costs - China, for example. In addition, the Korean shipbuilding industry also expanded production activities to overseas. Hyundai, for example, established shipyards in Vietnam (Hyundai Vinashin Shipyard) and China (Hyundai Qindao Shipyard), while Samsung established a shipyard in Brazil (see Table 5, and also Hong, 2008, p. 32). Daewoo and Hanjin also moved in to Romania as early as 1997 and the Philippines respectively, while STX Group recently bought a major Norwegian shipyard, Aker Yards, and renamed it STX Europe. In this way, parts and materials not only for higher-end products but also for medium value-added ships tend to create extra-cluster linkages with the Korean shipbuilding cluster.

(TABLE 5 ABOUT HERE) 
At the present time, the firms contained in the cluster have not formed dynamic R\&D networks; rather they interact only in a vertical way. Horizontal interactions are not well developed. Large shipbuilders, such as Samsung and Hyundai, do not actively interact with each other but compete. Therefore, it can be said that local buzz is limited to only certain levels, such as within conglomerate among the group formed by a large shipbuilding company such as Samsung and Hyundai, or certain local industrial parks. However, they exchange information and share common interests to take advantage of outside assistance, such as those from the government, universities, and public research organizations. They also cooperate to work for, or against, outside supporters, or competitors at home and overseas.

\section{Conclusions}

On the basis of the qualitative empirical analysis of the cluster life cycle, we can derive several conclusions related to the research questions posed at the end of Section 2. First, different characteristics (Table 1) of the Korean shipbuilding cluster can be seen as existing at different stages of the life cycle. While the value chain and dynamics of the Korean cluster are at the 'maturation' stage, the determinant for success and the government's role are in the 'transition' stage, leaving strategic relations at the 'expansion' stage. In a cluster as a highly complex system consisting of large enterprises with different strategies, small and medium-sized suppliers and different political actors at national and regional level, it is highly unlikely that all characteristics are positioned in the same stage of development. Future research is needed to elaborate more on this co-evolutionary question. Secondly, and related to the first research question posed at the end of Section 2, clustered firms have become more competitive than non-clustered firms in the middle stages of the cluster life cycle. Thirdly, as is stated in the conceptual literature, 
shipbuilders have successfully specialized in the past, but are more recently re-orientating and diversifying into high-end market segments. Fourthly, the development of the number of entrants and exits through the course of the life cycle does not mirror the typical development stated in the conceptual literature (from many entrants and no exits to a few entrants and a few exits to hardly any entrants and many exits). Partly due to the specific characteristics of the South Korean shipbuilding industry with a few, but relatively large firms from the start, both the number of entrants and exits has been very low from the beginning. Fifthly, concerning the role of the government through the course of the life cycle, the Korean state has done much more than providing information on local know-how and market expansion in early stages, as indicated in the conceptual literature; it has invested heavily in these stages, as shipbuilding was a targeted industry. Sixthly, the heterogeneity of knowledge in the cluster decreased during the 1980s and 1990s, but more recently the Korean shipbuilding industry has been successfully diversifying the heterogeneity of knowledge in the cluster. Finally, concerning the geographic concentration of firms through the life cycle of the cluster, there has been a strong tendency of geographic concentration of the cluster in the past, but recently the cluster disperses and even internationalises. Extra-local linkages destined for other parts of Korea have been developed to simply expand the scale of production, while new international production linkages with an advanced shipbuilding country, such as Norway, have also been developed to take advantage of accumulated technology there. It is interesting to note that the Korean shipbuilding cluster continues to expand its linkages with other countries to acquire advanced skills and know-how, not simply cheap labour and parts.

Overall, we can also conclude that in a relatively small country such as South Korea with an industry that is relatively spatially concentrated, such as shipbuilding, industry and cluster life cycle do not differ that much from each other. The emergence of the cluster was neither an 
historical accident, nor played related industries located in the region play a decisive role. It was, instead, much more due to a deliberate central government strategy. As stated by MENZEL and FORNAHL (2010) and MARTIN and SUNLEY (2006), our case study confirms that a nondeterministic view on the life cycle of clusters is necessary. The exact course of a cluster life cycle and its characteristics vary from case to case and is therefore an empirical question. 


\section{References}

AmSDEN A. (1989) Asia's Next Giant: South Korea and Late Industrialization. Oxford University Press, New York, NY.

ASHeIM B., COOKE P. and MARTIN R. (Eds) (2006) Clusters and Regional Development; Critical Reflections and Explorations. Routledge, London and New York.

Auty R. M. (1990) The Impact of Heavy-industry Growth Poles on South Korean Spatial Structure, Geoforum 21, 23-33.

BAthelt H., Malmberg A. and MASKell P. (2004) Clusters and knowledge: local buzz, global pipelines and the process of knowledge creation, Progress in Human Geography 28, 31-56.

BOSCHMA R. and MARTIN R. (2010) The aims and scope of evolutionary economic geography, in BoschMA R. and MARTIN R. (Eds) Handbook of Evolutionary Economic Geography, pp. 3-39. Edward Elgar, Cheltenham.

Boschma R. A. and VAN DER KNAAP G. A. (1999) New High-Tech Industries and Windows of Locational Opportunity: the Role of Labour Markets and Knowledge Institutions During the Industrial Era, Geografiska Annaler B 81, 73-89.

Chapman K., MacKinnon D. and Cumbers A. (2004) Adjustment or Renewal in Regional Clusters? A Study of Diversification amongst SMEs in the Aberdeen Oil Complex, Transactions of the Institute of British Geographers 29, 382-396. 
CHO D. S. and PoRTER M. E (1986) Changing Global Industry Leadership: The Case of Shipbuilding, in PORTER M. E. (Ed) Competition in Global Industries, pp. 539-567. Harvard Business School Press, Boston.

CHUNG S. (2002) Building a National Innovation System through Regional Innovation Systems, Technovation 22, 485-491.

CUMBERS A. and MACKINNON D. (2004) Introduction: Clusters in Urban and Regional Development, Urban Studies 41, 959-969.

D’Costa A. P. (1994) State, Steel and Strength: Structural Competitiveness and Development in South Korea, Journal of Development Studies 31, 44-81.

EICH-BORN M. and HASSINK R. (2005) On the battle between Shipbuilding Regions in Germany and South Korea, Environment and Planning A 37, 635-656.

ENRIGHT M. (2003) Regional Clusters: What We Know and What We Should Know, in BRÖCKER J., DOHSE D. and SOLTWEDEL R. (Eds) Innovation Clusters and Interregional Competition. pp. 99-129. Springer, Berlin.

GARUd R. and KARnOe P. (2001) Path Creation as a Process of Mindful Deviation, in GARUd R.and Karnoe P. (Eds) Path Dependence and Creation, pp. 1-38. Lawrence Erlbaum Associates, London. 
GILSING V. and HosPers G.-J. (2000) De Levensloop van Clusters, Economische Statistische Berichten 85, D12-D14.

GLEN D. (2006) Shipbuilding Disputes: the WTO Panel Rulings and the Elimination of Operating Subsidy from Shipbuilding, Maritime Policy \& Management 33, 1-21.

HASSINK (2010) Locked in Decline? On the Role of Regional Lock-ins in Old Industrial Areas, in Boschma R. and MARTIN R. (Eds) Handbook of Evolutionary Economic Geography, pp. 450-468. Edward Elgar, Cheltenham.

HASSINK R. and KLAERDING C. (2009) Relational and evolutionary economic geography: competing or complementary paradigms? Papers in Evolutionary Economic Geography \# 09.11, Utrecht University.

HASSINK, R. and KLAERDING C. (2011) Evolutionary approaches to local and regional development policy, in PIKE A., Rodríguez-Pose A. and TOMANEY J. (Eds) A Handbook of Local and Regional Development, pp. 139-148. Routledge, London.

HASSINK R. and SHIN D.-H. (2005) South Korea's Shipbuilding Industry: From a Couple of Cathedrals in the Desert to an Innovative Cluster, Asian Journal of Technology Innovation 13, 133-155.

HASSINK R. and SHIN D.-H. (2008) From Daedeok to Teheran-ro: The Genesis and Development of New Industrial Spaces in South Korea, in RAmachandraiah C., VAn WeSten A. C. M. and PRASAD S. (Eds) High-Tech Urban Spaces - Asian and European Perspectives, 
pp. 149-172. Manohar, New Dehli.

HoNG S.-I. (2008) Global Competition and Differentiation Strategy. KIET Industry and Economy, September, 25-36 (in Korean).

Kim H-C, LEE C.-S. AND CHANG S. (2005) Technological Cooperation for Sustaining the First Rank in Shipbuilding in the World, Journal of the Korean Shipbuilding Society 44(2), 315 (in Korean).

KIM J.-K. (2008) Sustaining and Strengthening of the Competitiveness of Kyeongnam's Shipbuilding Industry, Changwon, Korea: Gyeongnam Development Institute (in Korean).

KIM S. (2006) Developmental States and the WTO: The Shipbuilding Industry in Korea. Paper Presented to the Second Oceanic Conference on International Studies, 5-7 July 2006, University of Melbourne.

KLEPPER S. (2007) The Evolution of Geographic Structures in New Industries, in FRENKEN K. (Ed) Applied Evolutionary Economics and Economic Geography, pp. 69-92. Edward Elgar, Cheltenham.

Korean NATIONAL StAtistical OfFICE (2008) Report on 2007 Census of the Manufacturing Establishments. Daejeon, Korea.

KOSHIPA (2008) Shipbuilding Korea 2008. Seoul: The Korea Shipbuilders’ Association. 
KOSHIPA (2009) A History of Developing Korean Shipbuilding Industry (available at: http://www.koshipa.or.kr) (accessed on 10 July 2009) (in Korean).

KOSHIPA (2010). Amount of Shipbuilding Tonnage by Selected Korean Major Companies (available at: Error! Hyperlink reference not valid.) (accessed on 30 April 2010) (in Korean).

KOSIS (Korean Statistical Information System), Report on the Census of the Manufacturing Establishments (available at: http://www.kosis.nso.go.kr) (accessed on 30 April 2010) (in Korean).

Krugman P. (1991) Geography and Trade. MIT Press: Cambridge, Massachusetts.

LEE J.-H. and RYU T.-Y. (2008) Spatial Concentration and Locational Characteristics of the Shipbuilding Industry in the South-East Region of Korea, Journal of the Korean Regional Geographical Association 14 (5), 512-535 (in Korean).

LEE Y.-S. (2009) Balanced Development in Globalizing Regional Development? Unpacking the New Regional Policy of South Korea, Regional Studies 43, 353-367.

LORENZEN M. (2005) Why Do Clusters Change?, European Urban and Regional Studies 3, 203208.

Markusen A. (1999) Fuzzy Concepts, Scanty Evidence and Policy Distance: The Case for 
Rigour and Policy relevance in Critical Regional Studies, Regional Studies 33, 869-886.

Martin R. and SunLey P. (2003) Deconstructing Clusters: Chaotic Concept or Policy Panacea?, Journal of Economic Geography 3, 5-36.

\author{
Martin R. and SunLey P. (2006) Path Dependence and Regional Economic Evolution, Journal \\ of Economic Geography 6, 395-437.
}

MinistRy OF FINANCE AND ECONOMY (1999) White Paper on the Economy. (in Korean). Seoul.

MENZEL M.-P. and FoRNAHL D. (2010) Cluster life cycles—dimensions and rationales of cluster evolution, Industrial and Corporate Change 19, 205-238.

OECD (2001) Innovative Clusters: Drivers of National Innovation Systems. Paris, OECD.

OECD (2007) Competitive Regional Clusters. Paris, OECD (Reviews of Regional Innovation).

PARK S. O. and MARKUSEN A. (1999) Kumi and Ansan: Dissimilar Korean Satellite Platforms, in Markusen A., LeE Y.-S. and Digiovanni S. (Eds) Second Tier Cities: Rapid Growth beyond the Metropolis, pp. 147-162. University of Minnesota Press, Minneapolis.

PopP A. and Wilson J. (2007) Life Cycles, Contingency, and Agency: Growth, Development, and Change in English Industrial Districts and Clusters, Environment and Planning A 39, $2975-2992$. 
PORTER M. E. (2000) Location, Competition, and Economic Development: Local Clusters in a Global Economy, Economic Development Quarterly 14, 15-34.

PRESS K. (2006) A Life Cycle for Clusters? The Dynamics of Agglomeration, Change, and Adaption. Physica-Verlag, Heidelberg, New York.

SAMSUNG HeAvy IndUSTRIES (2009a) Products and Technology: MegaBlock Technology (available at: http://www.shi.samsung.co.kr) (accessed on 25 May 2009) (in Korean).

SAMSUNG HEAVy INDUSTRIES (2009b) Thirty-year History of Samsung Heavy Industries, Samsung Heavy Industries, Seoul (in Korean).

SAXENIAn A. (1994) Regional Advantage: Culture and Competition in Silicon Valley and Route 128. Harvard University Press, Cambridge, Massachusetts and London:.

ScotT A. J. (1988) New Industrial Spaces. Pion, London.

SHIN D. H. (2001) An alternative approach to developing science parks: A case study from Korea, Papers in Regional Science 80, 103-111.

STOPFORD M. (2008) SMM 2008 Advance Press Conference: World Shipbuilding. Hamburg, 29th May 2008.

StOPFORD M. (2009) Maritime Economics. Routledge, London and New York. 
STORPER M. (1997) The Regional World: Territorial Development in a Global Economy. The Guilford Press, New York, London.

STORPER M. and WALKER R. (1989) The Capitalist Imperative. Blackwell, Oxford.

VAN KLINK A. and De LANGEN P. (2001) Cycles in Industrial Clusters: the Case of the Shipbuilding Industry in the Northern Netherlands, Tijdschrift voor Economische en Sociale Geografie 92, 449-463.

Woo Y.-S. (2003) A Study on the Technology Cooperation Networks of Shipbuilding, Journal of the Korean Regional Science Association 19, 19-40 (in Korean).

Woo Y.-S. (2005) A Study on the Restructuring of Shipbuilding Industry and the Structure of Community Cooperation: The Case of Sinhyeon-eup in Geoje, Journal of the Korean Geographical Society 40 (4), 19-40 (in Korean). 
Fig. 1. Interaction between size and heterogeneity of clusters over the life cycle

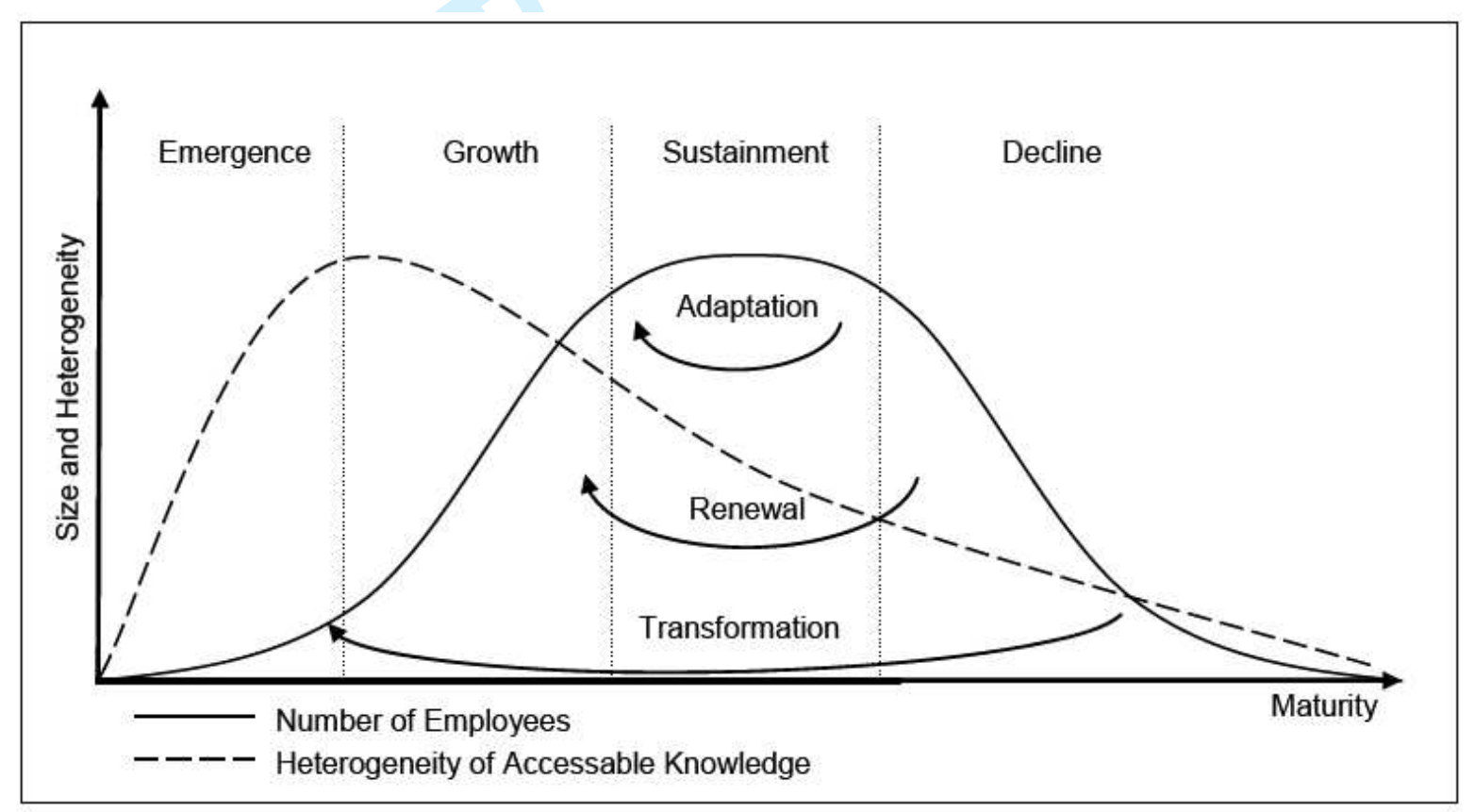

Source: MENZEL and FORNAHL (2010, p. 218). 
Fig. 2. Clustered and Non-clustered Companies during the Industry Life Cycle

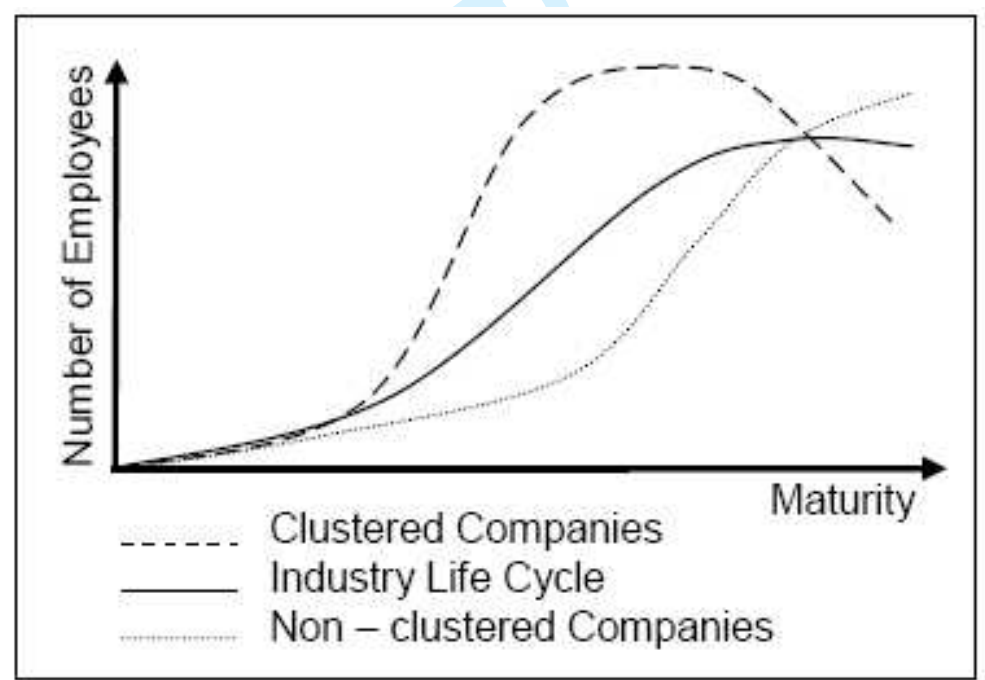

Source: MENZEL and FORNAHL (2010, p. 211). 
Fig. 3. The development of the world market shares in merchant shipbuilding

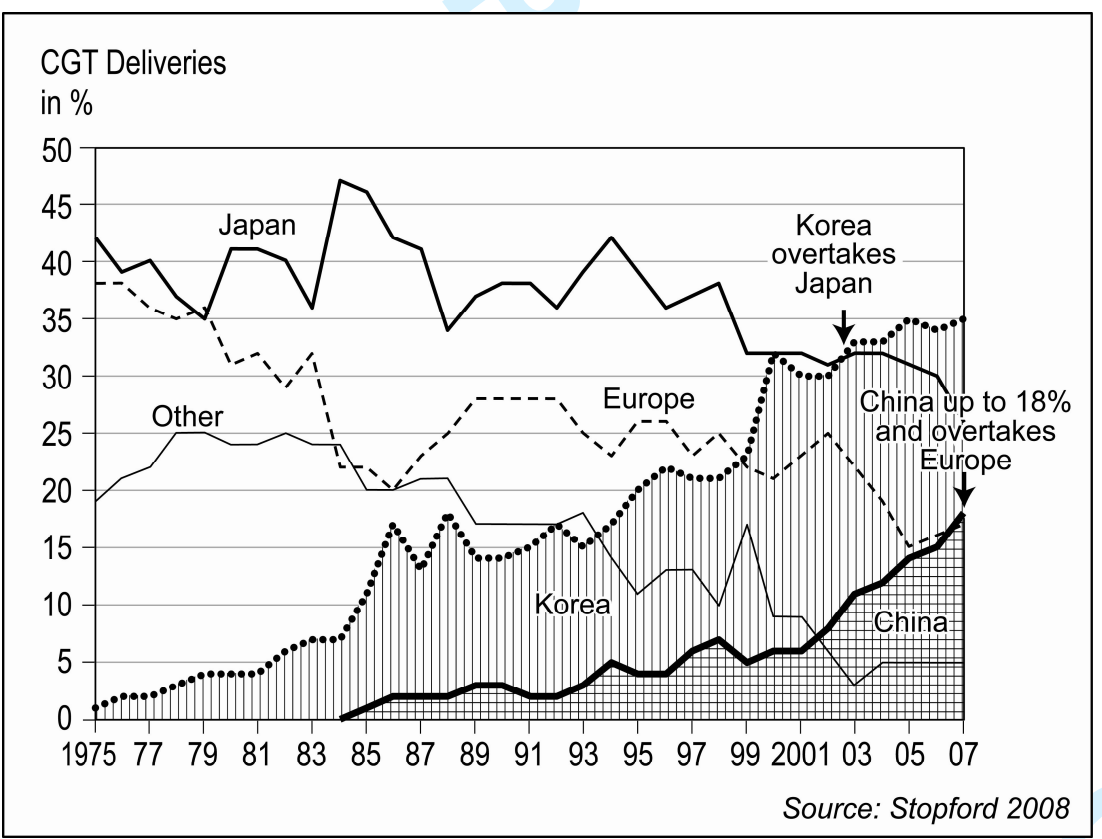

Source: STOPFORD, 2008. 
Fig. 4. Major Locations of Shipbuilding Activities in Korea

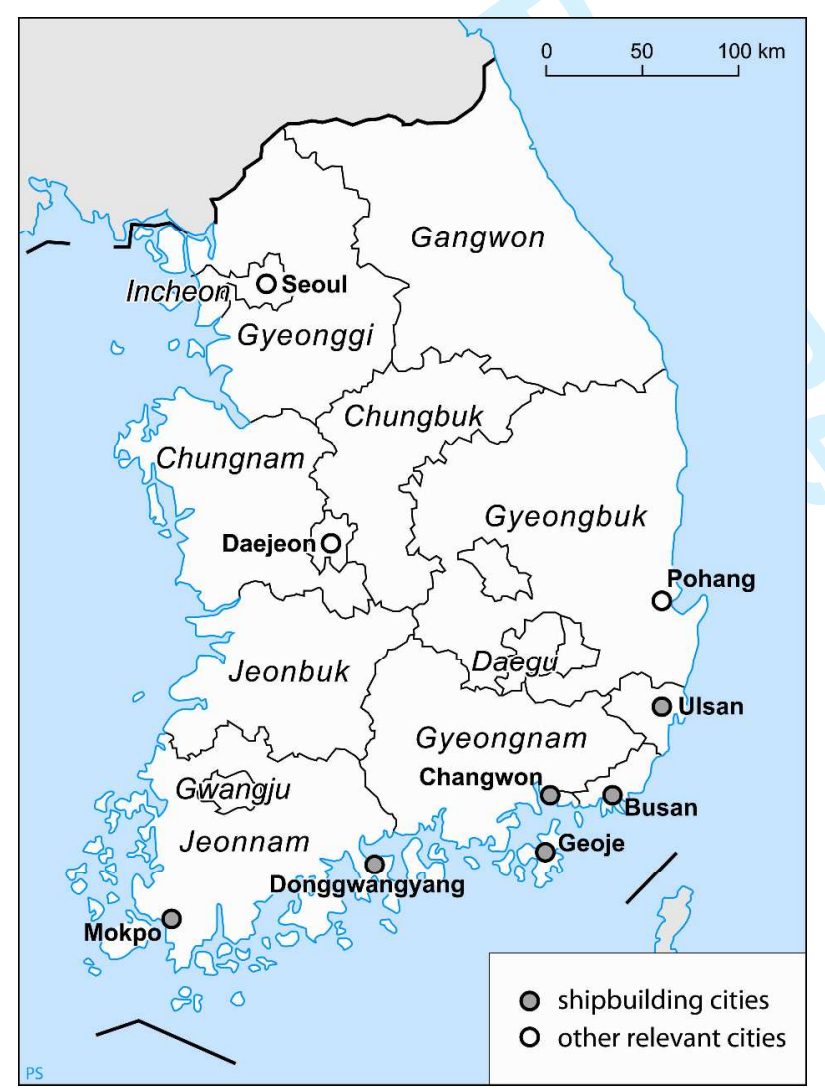

Source: own research, based on Koshipa, 2008. 
Table 1. A cluster life cycle

\begin{tabular}{|l|l|l|l|l|}
\hline & Development & Expansion & Maturation & Transition \\
\hline $\begin{array}{l}\text { Character of the } \\
\text { Value Chain }\end{array}$ & $\begin{array}{l}\text { Construction of a } \\
\text { value chain with } \\
\text { different firms }\end{array}$ & $\begin{array}{l}\text { Specialisation } \\
\text { among firms } \\
\text { in the chain }\end{array}$ & $\begin{array}{l}\text { Stable roles of } \\
\text { firms in the value } \\
\text { chain }\end{array}$ & $\begin{array}{l}\text { Reorientation of } \\
\text { the roles of firms } \\
\text { in the chain }\end{array}$ \\
\hline $\begin{array}{l}\text { Strategic } \\
\text { Relations }\end{array}$ & $\begin{array}{l}\text { Development of } \\
\text { strategic relations }\end{array}$ & $\begin{array}{l}\text { Strengthening } \\
\text { of strategic } \\
\text { relations }\end{array}$ & $\begin{array}{l}\text { Pressure on } \\
\text { strategic } \\
\text { relations }\end{array}$ & $\begin{array}{l}\text { Reconfiguration } \\
\text { of strategic } \\
\text { Relations }\end{array}$ \\
\hline $\begin{array}{l}\text { Cluster } \\
\text { Dynamics }\end{array}$ & $\begin{array}{l}\text { Some entrants, } \\
\text { no exits }\end{array}$ & $\begin{array}{l}\text { Some } \\
\text { entrants, no } \\
\text { exits }\end{array}$ & $\begin{array}{l}\text { Few entrants, } \\
\text { few exits }\end{array}$ & $\begin{array}{l}\text { Few entrants, } \\
\text { many exits }\end{array}$ \\
\hline Domain & $\begin{array}{l}\text { R\&D } \\
\text { Standardisation } \\
\text { Co-operative } \\
\text { Routines }\end{array}$ & $\begin{array}{l}\text { R\&D } \\
\text { Education } \\
\text { Marketing } \\
\text { Sharing } \\
\text { infrastructure }\end{array}$ & $\begin{array}{l}\text { R\&D } \\
\text { Education } \\
\text { Marketing }\end{array}$ & $\begin{array}{l}\text { R\&D } \\
\text { Education } \\
\text { New co- } \\
\text { operative } \\
\text { routines }\end{array}$ \\
\hline $\begin{array}{l}\text { Determinant for } \\
\text { success }\end{array}$ & $\begin{array}{l}\text { Presence of local } \\
\text { resources, } \\
\text { knowhow } \\
\text { and demanding } \\
\text { home market }\end{array}$ & $\begin{array}{l}\text { Presence of } \\
\text { local } \\
\text { resources, } \\
\text { know-how } \\
\text { and risk } \\
\text { capital }\end{array}$ & $\begin{array}{l}\text { Presence of local } \\
\text { know-how and } \\
\text { balance between } \\
\text { local and global } \\
\text { orientation }\end{array}$ & $\begin{array}{l}\text { Presence of } \\
\text { (new) local } \\
\text { resources and } \\
\text { know-how and } \\
\text { organising } \\
\text { Capacity }\end{array}$ \\
\hline $\begin{array}{l}\text { Government } \\
\text { Providing } \\
\text { information on } \\
\text { local know-how } \\
\text { outsourcing } \\
\text { and } \\
\text { market } \\
\text { expansion }\end{array}$ & $\begin{array}{l}\text { Professionalising } \\
\text { suppliers and } \\
\text { stimulating neue } \\
\text { Kombinationen }\end{array}$ & $\begin{array}{l}\text { Sombinationen } \\
\text { Stimulating neue }\end{array}$ \\
\hline
\end{tabular}

Source: VAN KLINK and DE LANGEN (2001, p. 453) 
Table 2. Amount of Shipbuilding Tonnage by Selected Korean Major Companies (Unit : GT)

\begin{tabular}{|c|c|c|c|c|c|}
\hline Companies & 1973 & 1980 & 1990 & 2000 & 2008 \\
\hline Hyundai & - & 518,565 & $1,801,100$ & $4,384,151$ & $3,662,642(92)$ \\
\hline Mipo & - & - & 3 & 75,000 & $1,309,508(10)$ \\
\hline Daewoo & - & & $1,101,100$ & $2,877,972$ & $2,095,370(39)$ \\
\hline Hanjin & 2,980 & 60,448 & 129,900 & 780,113 & $453,824(13)$ \\
\hline Samsung & - & 13,858 & 408,500 & $2,338,046$ & $2,462,926(53)$ \\
\hline Samho & - & - & & 580,078 & $1,167,830(32)$ \\
\hline Tacoma & - & 252 & 2,176 & - & \\
\hline Donghae & - & 13,629 & & - & \\
\hline STX & 2,195 & 23,099 & 17,691 & 376,386 & $1,010,226(55)$ \\
\hline Daeseon & 5,628 & 9,365 & 24,540 & 4,400 & $106,092(10)$ \\
\hline Shinah & - & 7,640 & 13,958 & 82,300 & $197,575(12)$ \\
\hline Others & 485 & 8,075 & 73,034 & 780113 & \\
\hline Total & 11,288 & 654,931 & $3,571,999$ & $12,278,559$ & $12,465,993$ \\
\hline
\end{tabular}

Note: The number in ( ) in 2008 column means the number of ships built.

Source: KOSHIPA (2010) 
Table 3. Korea's Shipbuilding Activities by Regions

\begin{tabular}{|c|c|c|c|c|c|c|c|c|c|c|c|}
\hline \multirow{2}{*}{\multicolumn{2}{|c|}{$\begin{array}{l}\text { Regions } \\
\text { Regions }\end{array}$}} & \multicolumn{5}{|c|}{ No of Establishments } & \multicolumn{5}{|c|}{ No of Employees } \\
\hline & & 1994 & 1997 & 2000 & 2004 & 2007 & 1994 & 1997 & 2000 & 2004 & 2007 \\
\hline \multicolumn{2}{|l|}{ Busan $(\%)$} & 21.2 & 23.3 & 18.4 & 15.7 & 16.0 & 9.4 & 8.6 & 6.2 & 6.8 & 5.8 \\
\hline \multicolumn{2}{|c|}{ Gyeongnam (\%) } & 34.2 & 32.7 & 35.3 & 43.0 & 48.7 & 82.0 & 37.4 & 39.1 & 43.2 & 49.3 \\
\hline \multicolumn{2}{|l|}{ Ulsan (\%) } & N.A. & 4.2 & 10.6 & 14.3 & 12.0 & N.A. & 40.1 & 42.7 & 38.8 & 33.2 \\
\hline \multicolumn{2}{|c|}{$\begin{array}{l}\text { Three Area Total } \\
\text { (Busan, Gyeognam and } \\
\text { Ulsan, \%) }\end{array}$} & 55.3 & 60.2 & 64.3 & 73.0 & 76.7 & 91.4 & 86.1 & 88.0 & 88.8 & 88.4 \\
\hline \multicolumn{2}{|c|}{ Jeonnam (\%) } & 13.6 & 14.3 & 12.0 & 14.7 & 12.1 & 2.9 & 10.1 & 7.7 & 8.7 & 8.7 \\
\hline \multicolumn{2}{|c|}{ Other areas $(\%)$} & 31.1 & 25.5 & 23.8 & 12.3 & 11.2 & 5.7 & 3.8 & 4.3 & 2.5 & 2.9 \\
\hline \multirow{2}{*}{ Korea Total } & $\begin{array}{l}\text { Actual } \\
\text { Number }\end{array}$ & 1,101 & 1,205 & 1,301 & 1,100 & 1,628 & 64,979 & 77,892 & 81,502 & 94,197 & 121,534 \\
\hline & Percent $(\%)$ & 100.0 & 100.0 & 100.0 & 100.0 & 100.0 & 100.0 & 100.0 & 100.0 & 100.0 & 100.0 \\
\hline
\end{tabular}

Note: The 1997 data for Ulsan are 'Not Available' because Ulsan was a part of Gyeongnam Province prior to 1997.

Source: Census of the Manufacturing Establishments, Published by the Korean National Statistical Office, available from KOSIS (KOREAN STATISTICAL INFORMATION SYSTEMS, http://www.kosis.nso.go.kr) 
Table 4. Major Locations of Population Size and Shipbuilding Activities

\begin{tabular}{|l|r|r|l|}
\hline Regions & $\begin{array}{l}\text { Population } \\
(000)\end{array}$ & $\begin{array}{l}\text { No of } \\
\text { Shipbuilding } \\
\text { Companies }\end{array}$ & $\begin{array}{l}\text { No of Shipbuilding } \\
\text { Employees }\end{array}$ \\
\hline Seoul & 10,201 & & \\
Busan & 3,564 & $260(16.0)$ & $7.0(5.8)$ \\
Daejeon & 1,461 & & \\
Pohang & 508 & $196(12.0)$ & $60.4(33.2)$ \\
Ulsan & 1,12 & $793(48.7)$ & $10.6(8.7)$ \\
Gyeongnam & 5,225 & & \\
Changwon & 504 & $197(12.1)$ & \\
Geoje & 1,919 & & $1215(100.0)$ \\
Jeonnam & 246 & & \\
Mokpo & 508 & & \\
Dongkwangyang & 49,540 & $1628(100.0)$ & \\
\hline Korea Total & & & \\
\hline
\end{tabular}

Note: Numbers in brackets mean the share of the particular region.

Source: Population statistics of the cities and provinces were obtained from a statistical book of Korean Residents' Registration, representing the data for 2007, while industry statistics from the Report on the Census of the Manufacturing Establishments (published by the Korean NATIONAL StATISTICAL OfFICE). Both are available from KOSIS (Korean Statistical Information System, www.kosis.nso.go.kr). 
Table 5. Overseas Investment of Korean Shipbuilders

\begin{tabular}{|l|l|}
\hline Companies & Overseas Investment \\
\hline Hyundai Heavy Industries (HHI) & $\begin{array}{l}\text { Hyundai Vinashin Shipyard (HVS), Vietnam } \\
\text { Hyundai Qindao Shipyard, China }\end{array}$ \\
\hline Samsung Heavy Industries (SHI) & EAS Shipyard, Brazilian \\
\hline $\begin{array}{l}\text { Daewoo Shipbuilding \& Marine } \\
\text { Engineering (DSME) }\end{array}$ & $\begin{array}{l}\text { Daewoo Mangalia Heavy Industries Co., Ltd. } \\
\text { (DMHI), Romania }\end{array}$ \\
\hline STX Group & $\begin{array}{l}\text { STX Europe, Norway (Aker Yards) } \\
\text { The Dalian complex, China }\end{array}$ \\
\hline $\begin{array}{l}\text { Hanjin Heavy Industries \& } \\
\text { Construction (Hanjin) }\end{array}$ & Philippine Subic Bay Metropolitan Authority \\
\hline
\end{tabular}

Source: Hong (2008, p. 33) 